\title{
E-LKPD Materi Pecahan dalam Pembelajaran di Sekolah Dasar
}

\section{Gede Yoga Mahardika Arsa Putra ${ }^{1 *}$, I Made Suarjana ${ }^{2}$, I Gusti Ayu Tri Agustiana ${ }^{3}$}

1,2,3 Program Studi Pendidikan Guru Sekolah Dasar, Universitas Pendidikan Ganesha, Singaraja, Indonesia

\section{ART ICLE INFO}

Article history:

Received May 09, 2021

Revised May 15, 2021

Accepted June 23, 2021

Available online July 25, 2021

Kata Kunci:

LKPD Berbasis Daring, Pecahan

Keywords:

LKPD Based Online, Fraction

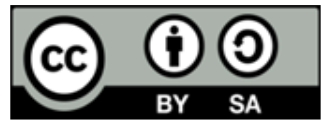

This is an open access article under the CC BY-SA license.

Copyright $(\subset 2021$ by Author. Published by Universitas Pendidikan Ganesha.

\begin{abstract}
A B S T R A K
Adanya COVID-19 membuat proses pembelajaran dilakukan di rumah (daring) sehingga pembelajaran menjadi kurang efektif. Oleh sebab itu, diperlukan suatu media yang menarik yang dapat memotivasi siswa dalam belajar, salah satunya adalah LKPD. Penelitian ini bertujuan untuk mengembangkan media LKPD pelajaran matematika materi operasi pecahan berbasis daring. Penelitian ini merupakan penelitian pengembangan yang dilaksanakan dengan menggunakan model pengembangan ADDIE. Subjek penelitian ini adalah 2 orang ahli materi dan 2 orang ahli media. Metode pengumpulan data yang digunakan adalah metode kuesioner dengan memberikan lembar penilaian kepada responden. Instrumen yang dipakai dalam mengukur tingkat validitas media LKPD adalah rating scale berupa lembar penilaian media LKPD dari ahli. Data yang diperoleh kemudian dianalisis dengan menggunakan rumus persentase guna mengetahui skor persentase validitas media LKPD dan reliabelitasnya menggunakan alpha cronbach yang setelahnya dilakukan uji coba ke siswa. Persentase validitas materi media LKPD yang diperoleh adalah $90 \%$ dengan kualifikasi sangat baik dan reliabelitasnya memperoleh 0.918 dengan kualifikasi sangat kuat. Validitas media LKPD yang diperoleh adalah 95,92 \% dengan kualifikasi sangat baik dan reliabelitasnya memperoleh 0.748 dengan kualifikasi kuat. Sedangkan hasil uji coba ke siswa sebanyak 25 orang memperoleh hasil persentase $96 \%$ dengan kualifikasi sangat baik. Berdasarkan analisis tersebut maka dapat dikatakan bahwa media LKPD berbasis daring yang dikembangkan pada materi operasi pecahan dinyatakan valid dan layak digunakan dalam pembelajaran di kelas $\mathrm{V}$ Sekolah Dasar.
\end{abstract}

\section{A B S TR A C T}

The existence of COVID-19 makes the learning process carried out at home (online) so that learning becomes less effective. Therefore, we need an interesting media that can motivate students in learning, one of which is LKPD. This study aims to develop online-based LKPD media for mathematics lessons on fractional operations. This research is development research carried out using the ADDIE development model. The subjects of this study were 2 material experts and 2 media experts. The data collection method used is a questionnaire method by giving an assessment sheet to the respondents. The instrument used in measuring level of validity of the LKPD media is a rating scale in the form of an LKPD media assessment sheet from an expert. The data obtained were then analyzed using the percentage formula to determine percentage score of the validity of the LKPD media and its reliability using Cronbach's alpha which was then tested on students. The percentage of the validity of the LKPD media material obtained is $90 \%$ with very good qualifications and the reliability is 0.918 with very strong qualifications. The validity of the LKPD media obtained is $95.92 \%$ with very good qualifications and the reliability is 0.748 with strong qualifications. While the test results to 25 students obtained a percentage of $96 \%$ with very good qualifications. Based on this analysis, it can be said that the online-based LKPD media developed on the fraction operation material is declared valid and suitable for use in learning in fifth grade elementary school.

\section{PENDAHULUAN}

Matematika merupakan salah satu muatan pembelajaran yang terdapat di sekolah dasar. Sebagai sebuah muatan pembelajaran tentunya matematika perlu dibelajarkan dengan proses yang menarik dan tentunya bermakna. Selain itu, pembelajaran yang berpusat pada siswa menjadi sebuah inovasi dalam pembelajaran (Wibawa \& Arnawa, 2017). Proses pembelajaran muatan matematika idealnya bermuara pada peningkatan kemapuan berpikir tingkat tinggi, seperti: berpikir kritis, kemampuan pemecahan masalah, dan 
berpikir kreatif (Asriningtyas et al., 2018; Oktaviani et al., 2018; Prasasti et al., 2019). Peningkatan kemampuan tersebut akan terwujud apabila proses pembelajaran dilakukan dengan suatu pendekatan yang mampu membangun suasana menarik dan bermakna serta memfasilitasi siswa untuk terlibat langsung secara aktif dalam kegiatan pembelajaran (Egok, 2016; Rovers et al., 2018; Susilowati, 2018). Suatu pendekatan pembelajaran akan semakin efektif jika dipadukan dengan sebuah media yang sesuai dengan dengan karakteristik siswa dan materi yang dibahas. Media pembelajaran mempunyai pengaruh sangat besar terhadap peningkatan hasil belajar siswa. Hal ini karena media memiliki peran membantu guru sebagai penyampai pesan yang bersifat abstrak menjadi lebih konkret, sehingga lebih mudah dipahami oleh siswa (Pahlevi et al., 2019). Jadi, untuk menggunkan media pembelajaran yang berkualitas tentunya membatuhkan kempuan dan kreatifitas guru dalam merancang dan amenggunkan media pembelajaran.

Namun, sayangnya media yang digunakan untuk menunjang pembelajaran muatan matematika dilapangan masih terbatas. Media yang ada selama ini belum memfasilitasi peserta didik untuk menemukan sendiri konsep yang diajarkan yang bisa merangsang kreativitas peserta didik (Sutrimo \& Saharudin, 2019). Penelitian menyebutkan beberapa permasalahan dalam proses pembelajaran muatan matematika, yaitu: 1) proses pembelajaran berlangsung kurang bermakna; 2) guru mendominasi proses pembelajaran dengan ceramah; 3) keterbatasan media pembelajaran yang sesuai dengan karakteristik siswa dan topik bahasan (Fauzia, 2018; Hanifah et al., 2019; Tanjung \& Nababan, 2016). Masalah diatas menjadi semakin kompleks karena pada tahun 2020 Indonesia dilanda wabah berbahaya Covid-19. Akibat wabah ini proses pembelajaran tatap muka dialihkan menjadi pembelajaran daring. Peralihan yang secara tiba-tiba ini menimbulkan pergeseran dalam praktik pembelajaran (Scherer et al., 2021). Peralihan ini juga perlu memperhatikan secara lebih rinci lagi tentang kesiapan guru dan faktor-faktor pendukung lainnya seperti srtuktur pendukung dan sumber daya (Hung, 2016; Kebritchi et al., 2017). Ada beberpa tantangan dalam penerapan pembelajaran daring, meliputi: lemahnya penguasaan IT oleh guru, terbatasnya akses pengawasan siswa, siswa kurang aktif mengikuti pembelajaran, terbatasnya fasilitas pendukung, dan keterbatasan waktu dalam mendampingi anaknya saat pembelajaran daring (Asmuni, 2020). Hal ini menjadi sebuah tantangan nyata untuk guru dan siswa (Jr. et al., 2021; Mishra et al., 2020). Merujuk pada permasalah-permasalahan di atas, maka dirasa sangat perlu untuk mengatasinya sesegera mungkin. Jika masalah di atas tidak segera diatasi, maka akan berdampak pada kualitas lulusan yang dihasilkan nantinya.

Salah satu alternatif yang bisa dilakukan ditengah proses pembelajaran daring adalah mengembangkan lembar kerja peserta didik (LKPD) khususnya pada muatan matematika materi pecahan. LKPD yang akan dikembangkan diharapkan mampu memfasilitasi siswa untuk belajar secara mandiri, tetapi tetap masih bisa dikontrol oleh guru. LKPD merupakan sarana pendukung pembelajaran yang disusun sedemikian rupa, yang terdiri dari paparan materi secara singkat dan dilanjutkan dengan soal-soal sebagai latihan untuk mendukung pembelajaran yang bermakna. Melalui LKPD ini siswa diajak untuk mengaitkan konsep-konsep yang dipelajari, melatih keterampilan memecahkan masalah, kemampuan berpikir kritis dan mengkomunikasikan ide-ide mereka (Tirka \& Kusumawatin, 2017). Adanya LKPD dalam pembelajaran memiliki tujuan untuk merangsang agar terlibat aktif dengan materi yang dibahas. Proses pembelajaran yang menekankan pada keaktifan siswa menjadikan pembelajaran itu bermakna, yaitu pengetahuan siswa dikonversi menjadi sebuah pengalaman (Rahayu \& Budiyono, 2018). Selain itu, berbagai penelitian pengembangan LKPD pada muatan matematika di SD (Effendi et al., 2021; Faiqoh et al., 2019; Komarudin \& Permana, 2019; Septian et al., 2019). Namun, pengembangan LKPD pada penelitian-penelitian tersebut belum ada yang mengambil materi pecahan di kelas $\mathrm{V}$ dan semua LKPD yang dikembangkan masih berbasis cetak. Pada penelitian ini dikembangkan sebuah LKPD yang memiliki beberpa keunggulan, yaitu: 1) LKPD yang dikembangkan berbasis daring (wibesite); 2) dilengkapi dengan video, suara, dan gambar yang memudahkan siswa memvisualisasikan materi yang bersifat abstrak, 3) memiliki tampilan yang tentunya menarik; dan 4) nilai dari hasil kerja siswa akan langsung setelah siswa selesai mengerjakan latihan soalnya. Tujuan pengembangan media ini adalah untuk menghasilkan media pembelajaran yang tervalidasi. Lebih lanjut, melalui media yang tervalidasi diharakan media yang dikembangkan bisa diaplikasikan disetiap sekolah dan memberikan dampak yang signifikan terhadap peningkatan hasil belajar siswa.

\section{METODE}

Penelitian ini merupakan penelitian pengembangan Research and Development dengan model ADDIE (analysisis, design, development, implementation, evaluasion). Tujuan dari penelitian ini adalah mengembangkan suatu produk dalam bentuk LKPD materi pecahan yang berbasis daring dan menguji kelayakan dari media pembelajaran, yang mana produk ini dipakai dalam pembelajaran matematika materi pecahan kelas V SD. Pengujian ini dilaksanakan untuk mendapatkan data serta informasi apakah LKPD pelajaran metematika materi pecahan berbasis daring untuk kelas V ini layak digunakan dalam kegiatan pembelajaran. Adapun tahapantahapan serta gambar bagan dari model 4D dapat pada gambar 1. Tahap analyse dilakukan dengan menganalisis Kebutuhan, menganalisis kurikulum, menganalisis media. Analisis kebutuhan dilakukan bertujuan 
untuk mengetahui kebutuhan siswa dan guru saat proses pembelajaran berlangsung. Analisis kebutuhan dilakukan dengan cara menyebar kuesioner pada guru kelas V di SD terkait dengan media yang cocok diterapkan di sekolah dasar pada pembelajaran daring. Pada analisis kurikulum dikalukan dengan mengkaji silabus, KI, KD, dan indikator pada topik pecahan siswa kelas V SD pada buku siswa. Hasil analisis digunakan sebagai acuan pengembangan materi pada media LKPD. Selanjutnya pada analisis media dilakukan guna mengumpulkan informasi kriteria media yang baik dan bermanfaat, sehingga dapat dijadikan sebagai acuan referensi dalam penelitian dan bermanfaat, sehingga dapat dijadikan sebagai acuan referensi dalam penelitian dan analisis kebutuhan dilakukan bertujuan untuk mengetahui kebutuhan siswa dan guru saat proses pembelajaran berlangsung. Setelah analisis dilaksanakan, selanjautnya adalah perancangan (design). Tahap ini bertujuan untuk merancang media berdasarkan analisis yang telah dilaksanakan sebelumnya. Proses pembuatan media LKPD berbasis daring diawali dari pemilihan ukuran kertas, merancang desain, materi, dan soal-soalnya menggunakan aplikasi Microsoft word, kemudian di simpan dalam bentuk PDF, dilanjutkan dengan proses mengunggah file tirsebut ke website liveworksheets dan mengedinnya menjadi LKPD berbasis daring (elektronik) video dan kunci jawan dari soal-soal yang ada. Tahap development media sudah bisa dibuat sesuai hasil dari rancangan dan serta telah dikonsultasikan dengan dosen pembimbing, jika media telah selesai dikembangkan maka bisa melanjutkan ke tahap penilaian melalui uji penilaian dari uji ahli media, uji ahli materi, dan respons siswa untuk melakukan review media LKPD yang sudah dikembangkan. Tahap implementation hasil dari pengembangan diaplikasikan saat proses pembelajaran guna mengetahui bagaimana pengaruh keefektifan, kemenarikan, dan efisiensi pembelajaran dengan menggunakan LKPD berbasis daring yang telah dikembangkan. Karena kondisi di lapangan serta situasi yang tidak memungkinkan tahap ini tidak dapat dilakukan. Tahap evaluation merupakan tahap terakhir, tahap ini dilakukan penilaian secara objektif untuk mengetahui kualitas media LKPD dan untuk mengetahuiapakah media LKPD yang telah dikembangkan ini dapat mempengaruhi hasil belajar siswa yang signifikan. Karena kondisi di lapangan serta situasi yang tidak memungkinkan tahap ini tidak dapat dilakukan.

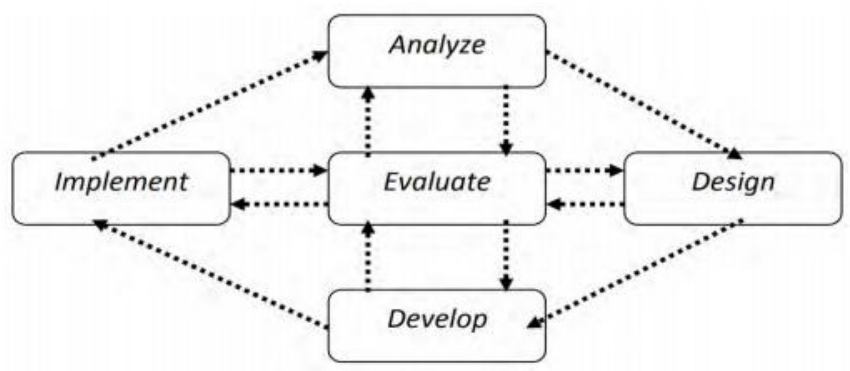

Gambar 01. Bagan Model 4D

(Sumber: Tegeh, et al., 2015)

Subjek pada penelitian pengembangan ini adalah para ahli yang berkompeten dibidangnya, dimana para ahli tersebut terdiri dari 2 orang ahli materi, 2 orang ahli media, dan 25 orang siswa. Selanjutnya metode pengumpulan data dilakukan dengan metode kuesioner, yaitu dengan memberikan sebuah daftar pertanyaan atau pernyataan-pernyataan kepada responden. Sedangkan Instrumen yang digunakan pada penelitian, yaitu rating scale. Skala yang digunakan pada rating scale adalah 1-4 (Ilhami \& R, 2017). Adapun kisi-kisi lembar validasi LKPD pembelajaran dapat dilihat pada Tabel 1, 2 dan 3. Instrumen yang telah disusun selanjutnya dilakukan tahap uji validitas. Uji validitas dilakukan untuk mengetahui tingkat kevalidan instrumen tersebut dengan menggunakan rumus Alpha Cronbach. Setelah data terkumpul dengan menggunakan instrumen tersebut, selanjunya akan dilakukan analisis data dengan teknik analisis deskriptif kualitatif dan analisis deskriptif kuantitatif. Data kualitatif merupakan data yang diperoleh pada tahap review ahli berupa saran dan komentar, selanjutnya dari data tersebut dilakukan perbaikan terhadap media yang dikembangkan sesuai dengan saran dan komentar yang diberikan sehingga menjadi media yang lebih baik lagi. Sedangkan data kuantitatif merupakan data yang diperoleh pada tahap review ahli berupa skor pada lembar penilaian, kemudian data tersebut dihitung rata-ratanya dengan menggunakan rumus mean guna mendapatkan hasil validitas dari media yang dikembangkan. Setelah rata-ratanya diperoleh selanjutnya dikonversikan dengan tabel konversi tingkat pencapaian skala 5 .

Tabel 1. Kisi-Kisi Instrumen Ahli Materi

\begin{tabular}{lllc}
\hline No & Indikator & \multicolumn{1}{c}{ Sub Indikator } & No. Item \\
\hline \multirow{3}{*}{1} & \multirow{2}{*}{ Kualtias isi } & Kesesuaian materi dengan indikator pecahan & 1 \\
& & Kebenaran konsep materi pecahan & 2 \\
& & Materi Pecahan dijelaskan dalam LKPD secara jelas dan mudah dipahami. & 3 \\
\hline
\end{tabular}




\begin{tabular}{|c|c|c|c|}
\hline No & Indikator & Sub Indikator & No. Item \\
\hline \multirow{6}{*}{2} & \multirow{7}{*}{$\begin{array}{l}\text { Keakuratan } \\
\text { Materi dan } \\
\quad \text { soal }\end{array}$} & Kesesuaian simulasi, gambar dan video dengan materi pecahan & 4 \\
\hline & & $\begin{array}{l}\text { LKPD berbasis daring dikembangkan secara jelas, lengkap dan mudah } \\
\text { dipahami }\end{array}$ & 5 \\
\hline & & Keakuratan konsep dan definisi & 6 \\
\hline & & Keakuratan gambar, simulasi, video yang terdapat pada LKPD & 7 \\
\hline & & Keakuratan materi pada LKPD & 8 \\
\hline & & Keakuratan soal-soal pecahan pada LKPD & 9 \\
\hline \multirow{6}{*}{3} & & Evaluasi sesuai dengan materi & 10 \\
\hline & \multirow{5}{*}{$\begin{array}{l}\text { Keakuratan } \\
\text { soal-soal } \\
\text { literasi sains } \\
\text { pada LKPD }\end{array}$} & Kesesuaian materi dan soal pecahan dengan pelajaran matematika & 11 \\
\hline & & $\begin{array}{l}\text { Penyajian simulasi, gambar dan video mudah dipahami dan sesuai } \\
\text { dengan materi pecahan }\end{array}$ & 12 \\
\hline & & Penyajian evaluasi mudah dipahami dan sesuai dengan materi pecahan & 13 \\
\hline & & Penggunaan soal-soal mencakup penerapan pada kehidupan sehari-hari & 14 \\
\hline & & Materi memberikan pengalaman belajar & 15 \\
\hline
\end{tabular}

(Dimodifikasi dari Permata, 2019)

Tabel 2. Kisi-kisi Instrumen Ahli Media

\begin{tabular}{|c|c|c|c|}
\hline No & Indikator & No. Item & Sub Indikator \\
\hline \multirow{17}{*}{1} & \multirow{17}{*}{ Desain LKPD } & 1 & Kejelasan dan kelengkapan isi LKPD \\
\hline & & 2 & Kejelasan judul LKPD \\
\hline & & 3 & Kejelasan rumusan tujuan \\
\hline & & 4 & Kesesuaian tipe LKS dengan karakteristik kompetensi \\
\hline & & 5 & Kejelasan petunjuk LKPD \\
\hline & & 6 & Kejelasan uraian materi \\
\hline & & 7 & Kejelasan langkah-langkah kerja \\
\hline & & 8 & Kesesuaian langkah kerja dengan tujuan \\
\hline & & 9 & Ketepatan jenis dan ukuran kertas \\
\hline & & 10 & Kejelasan Bahasa \\
\hline & & 11 & Ketepatan jenis dan ukuran huruf \\
\hline & & 12 & Kejelasan gambar \\
\hline & & 13 & Kejelasan video \\
\hline & & 14 & Kejelasan suara video \\
\hline & & 15 & Kejelasan simulasi \\
\hline & & 16 & Desain media LKPD \\
\hline & & 17 & Kejelasan penilaian \\
\hline \multirow{6}{*}{2} & & 18 & kesesuaian tata letak simulasi, video dan Gambar \\
\hline & & 19 & Kombinasi warna LKPD yang digunakan sesuai dan terlihat menarik \\
\hline & Kemenarikan & 20 & Penggunaan tata Bahasa \\
\hline & Media & 21 & Soal tidak bermakna ganda \\
\hline & & 22 & Kemenarikan gambar \\
\hline & & 23 & Kemenarikan video \\
\hline \multirow{4}{*}{3} & Pemanfaatan & 24 & Kesesuaian penerapan LKPD dengan RPP \\
\hline & dan & 25 & Keaktifan siswa dalam pembelajaran \\
\hline & Pengelolaan & 26 & Kejelasan petunjuk pemanfaatan LKPD \\
\hline & LKPD & 27 & Ketepatan metode pemanfaatan LKPD \\
\hline
\end{tabular}

Tabel 3. Kisi-kisi Instrumen Peserta Didik

\begin{tabular}{|c|c|c|c|}
\hline No & Indikator & Sub Indikator & No. Item \\
\hline \multirow{4}{*}{1} & \multirow{4}{*}{ Tampilan Media } & Kejelasan gambar & 1 \\
\hline & & Kejelasan video & 2 \\
\hline & & Kejelasan simulasi & 3 \\
\hline & & Desain media LKPD & 4 \\
\hline \multirow{4}{*}{2} & & Tata letak simulasi, video dan gambar & 5 \\
\hline & Kemenarikan & Kombinasi warna LKPD yang digunakan sesuai dan terlihat menarik & 6 \\
\hline & Media & Kemenarikan gambar & 7 \\
\hline & & Kemenarikan video & 8 \\
\hline \multirow{2}{*}{3} & Kemudahan & Kemudahan dalam penggunanan & 9 \\
\hline & Penggunaan & Mendorong peserta didik menemukan sendiri prosedur/konsep & 10 \\
\hline
\end{tabular}




\section{HASIL DAN PEMBAHASAN}

Hasil

Penelitian ini bertujuan untuk menghasilkan media LKPD berbasis daring (LKPD elektronik) pada materi pecahan di kelas V Sekolah Dasar. Penelitian ini menggunakan model ADDIE yang terdiri dari 5 tahapan, yaitu, yang pertama analyze (analisis), kedua design (perancangan), ketiga development (pengembangan), keempat implementation (implementasi), dan yang kelima evaluation (evaluasi). Tahap analyze. Tahap analisis ditempuh melalui beberapa tahapan yakni: analisis kebutuhan, analisis kurikulum, dan analisis media yang baik. Analisis kebutuhan yang dilaksanakan pada pengembangan media yang digunakan di SD menggunakan metode kuesioner dan wawancara. Berdasarkan hasil kuesioner diperoleh bahwa: (1) 66,7\% sudah menggunakan LKPD bebasis daring (elektronik) namun materi dan videonya terpisah. (2) 66,7\% menyatakan bahwa LKPD berbasis daring (elektronik) sangat penting untuk dikembangkan dan 33,3\% menyatakan penting untuk dikembangkan. Sementara itu, dari 51 orang siswa 92,2\% menyatakan bahwa guru sudah menggunakan LKPD berbasis daring (elektronik) dalam pembelajaran namun materi dan videonya masih terpisah serta 56,9\% menyatakan bahwa LKPD berbasis daring ini sangat penting untuk dikembangkan dan 43,1\% menyatakan penting untuk dikembangkan. Pelaksanaan analyze kurikulum dilakukan dengan menganalisis KI, KD, dan Indikator yang termuat pada buku guru dan siswa yang dapat digunakan sebagai acuan dalam mengembangkan media. Kompetensi Dasar dan Indikator Pencapaian Kompetensi disajikan pada tabel 4.

Tabel 4. KD dan Indikator Pencapaian Kompetensi

\begin{tabular}{|c|c|}
\hline Kompetensi Dasar & Indikator Pencapaian Kompetensi \\
\hline $\begin{array}{l}\text { Menjelaskan dan melakukan penjumlahan dan } \\
\text { pengurangan dua pecahan dengan penyebut } \\
\text { berbeda. }\end{array}$ & $\begin{array}{l}\text { 3.1.1 Siswa dapat menjelaskan dan melakukan } \\
\text { penjumblahan dua pecahan dengan penyebut } \\
\text { berbeda } \\
\text { 3.1.2 Siswa dapat menjelaskan dan melakukan } \\
\text { pengurangan dua pecahan dengan penyebut } \\
\text { berbeda }\end{array}$ \\
\hline $\begin{array}{l}\text { 3.2 Menjelaskan dan melakukan perkalian dan } \\
\text { pembagian pecahan dan desimal. }\end{array}$ & $\begin{array}{l}\text { 3.2.1 Siswa dapat menjelaskan dan melakukan } \\
\text { perkalian pecahan biasa, campuran dan } \\
\text { desimal } \\
\text { 3.2.2 Siswa dapat menjelaskan dan melakukan } \\
\text { pembagian pecahan biasa, campuran dan } \\
\text { desimal }\end{array}$ \\
\hline $\begin{array}{l}\text { 4.1 Menyelesaikan masalah yang berkaitandengan } \\
\text { menjumlahan dan pengurangan dua pecahan } \\
\text { dengan penyebut berbeda. }\end{array}$ & $\begin{array}{l}\text { 4.1.1 Siswa dapat menyelesaikan masalah yang } \\
\text { berkaitan dengan penjumblahan dua pecahan } \\
\text { dengan penyebut berbeda } \\
\text { 4.1.2 Siswa dapat menyelesaikan masalah yang } \\
\text { berkaitan dengan pengurangan dua pecahan } \\
\text { dengan penyebut berbeda }\end{array}$ \\
\hline $\begin{array}{l}\text { 4.2 Menyelesaikan masalah yang berkaitan dengan } \\
\text { perkalian dan pembagian pecahan dan desimal. }\end{array}$ & $\begin{array}{l}\text { 4.2.1 Siswa dapat menyelesaikan masalah yang } \\
\text { berkaitan dengan perkalian pecahan biasa, } \\
\text { campuran dan desimal } \\
\text { 4.2.2 Siswa dapat menyelesaikan masalah yang } \\
\text { berkaitan dengan pembagian pecahan biasa, } \\
\text { campuran dan desimal }\end{array}$ \\
\hline
\end{tabular}

Selanjutnya pada analisis media dilakukan bertujuan agar medapatkan informasi terkait media yang digunakan pendidik dalam proses pembelajaran daring. Dalam pembelajaran daring yang sudah berlangsung, pendidik belum memanfaatkan fasilitas yang ada secara meksimal. Hal tersebut ditunjukan berdasarkan hasil data observasi yang diperoleh pada analisis. Dalam pengembangan media ini terdapat beberapa kriteria yang dipakai yang meliputi aspek sampul, format, isi, bahasa, kepraktisan. Aspek sampul meliputi judul LKPD, kemenarikan sampul, aspek format meliputi ukuran kertas, warna, tulisan, jenis huruf, dan tata letak, aspek isi meliputi kecocokan materi dengan tujuan pembelajaran, kemampuan media dalam menjelaskan materi, kelengkapan materi, vodeo pembelajaran dan daya tarik materi pada media, kriteria aspek bahasa meliputi pemakaian bahasa, kebakuan bahasa, keefektifan kalimat, dan pemakaian kata, serta kepraktisan media yang dikembangkan. Tahap design. Setelah analisis dilaksanakan, selanjautnya adalah perancangan (design). Tahap ini bertujuan untuk merancang media berdasarkan analisis yang telah dilaksanakan sebelumnya. Proses pembuatan media LKPD berbasis daring diawali dari pemilihan ukuran kertas, merancang desain, materi, dan soal-soalnya menggunakan aplikasi Microsoft word, kemudian di simpan dalam bentuk PDF, dilanjutkan dengan proses mengunggah file tirsebut ke website liveworksheets dan mengedinnya menjadi LKPD berbasis daring 
(elektronik) video dan kunci jawan dari soal-soal yang ada. Tahap development. Pada tahap pengembangan mulai dibuat media yang dikembangkan. Media yang dikembangkan terdiri dari cover, identitas peserta didik, petunjuk penggunaan, tujuan pembelajaran, bagian isi, serta latihan soal. Cover LKPD terdapat judul, identitas peserta didik, dan petunjuk belajar dengan warna dan jenis huruf yang menarik. Selanjutnya Pada halaman pertama LKPD terdapat tujuan pembelajaran dan materi pembelajaran. Pada bagian isi memuat tentang materi oprasi hitung penjumblahan, pengurangan, perkalian, dan pembagian bilangan pecahan semester 1 kelas V. Pada setiap LKPD juga terdapat video pembelajaran. Bagian terakhir media terdapat soal-soal dan kunci jawabannnya sudah di integrasikan didalmnya melalui program. Adapun tampilan LKPD yang telah dibuat dapat dilihat pada gambar 1. Setelah tahap pengembangan LKPD yang dihasilkan kemudian di uji validitasnya. Data hasil uji validitas materi dan media selanjutnya dianalisis untuk mengetahui validitas materi dan media yang dikembangkan. Analisis data dilakukan dengan menghitung jumblah keseluruhan skor yang diperoleh melalui lembar penilaian para ahli. Data tersebut kemudian dicari persentasenya untuk mengetahui kualifikasi validitas materi dan media yang dikembangkan. Berdasarkan review dari ahli materi mendapatkan skor $90 \%$ dengan kualifikasi sangat baik, dari ahli media mendapatkan skor 95, $92 \%$ dengan kualifikasi sangat baik. Setelah di uji cobakan selanjutnya dilaksanakan revisi media. Revisi media bertujuan untuk menyempurnakan media yang telah divalidasi oleh para ahli baik ahli materi maupun ahli media didapatkanlah saran dari validator untuk menyempurnakan media yang sudah dikembangkan. Adapun Hasil revisi media dapat dilihat pada tabel 5. Hasil dari uji coba media untuk aspek tampilan media sebesar 95,6\%, aspek pada kemenarikan media sebesar 95,6\%, aspek kemudahan penggunaan sebesar 96,8\%. Persentase keseluruhan dari 25 peserta didik memperolehan presentase sebesar $96 \%$. Berdasarkan hasil uji tersebut berarti bahwa kriteria media yang dikembangkan adalah sangat baik.
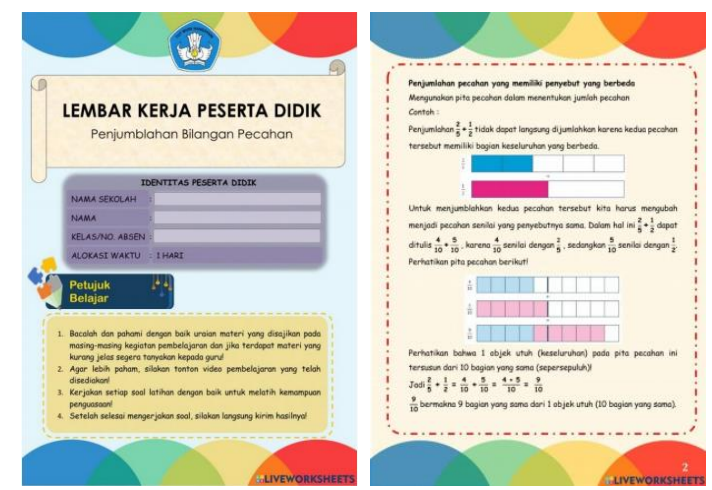

Gambar 1. Produk LKPD

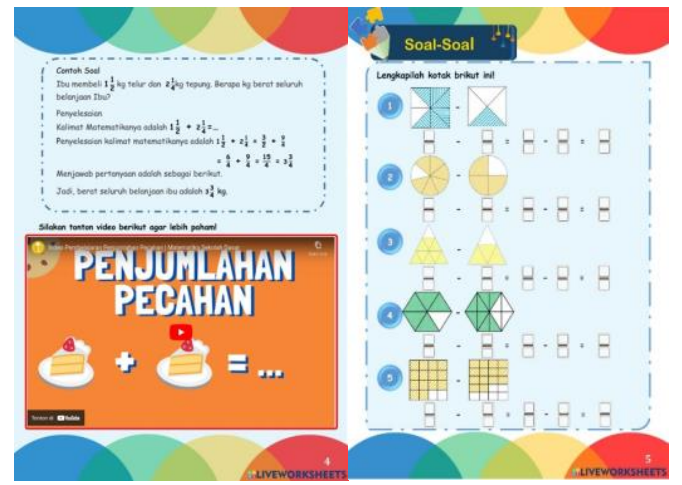

Tabel 5. Data Saran Ahli Materi dan Media

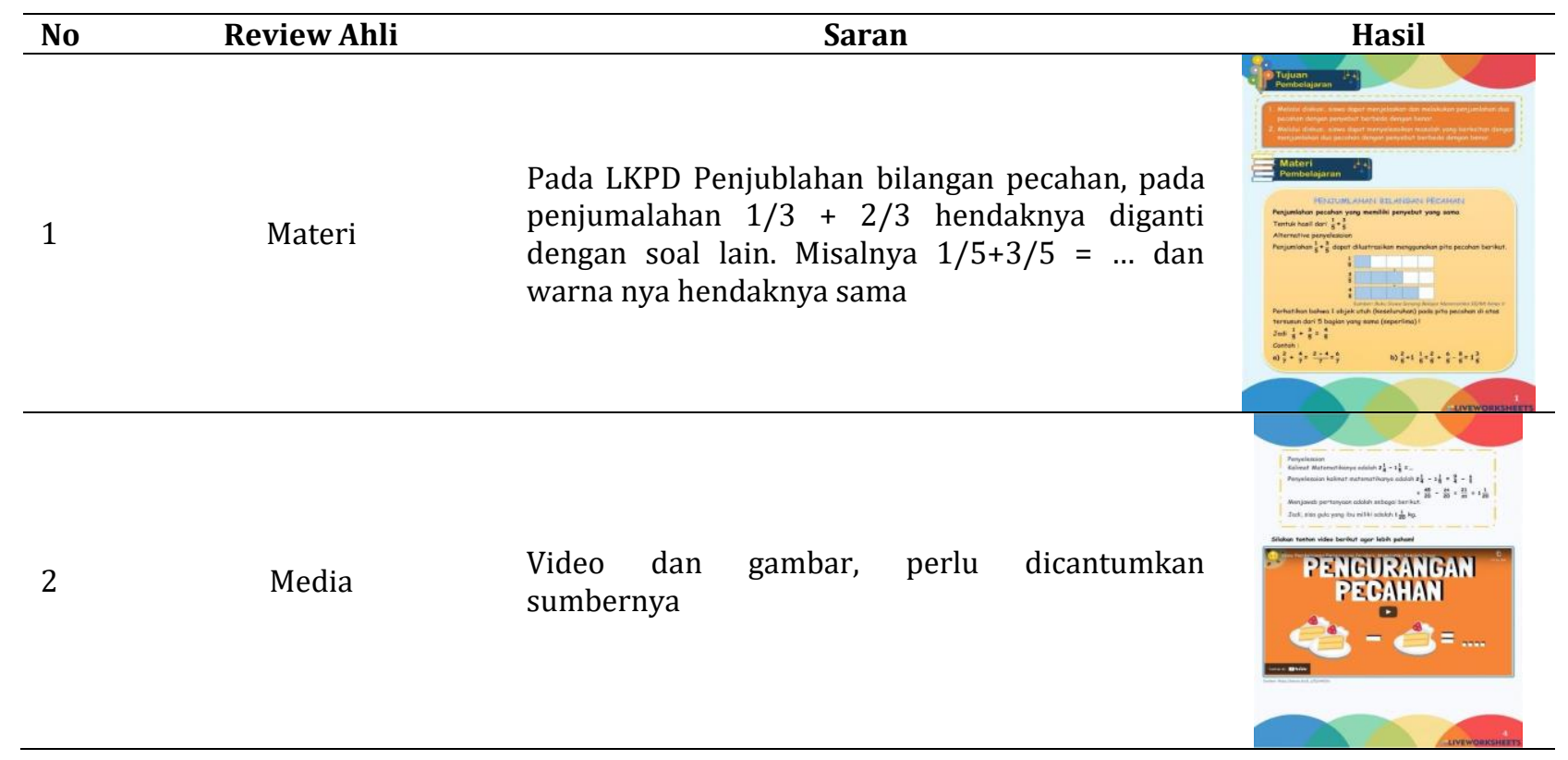




\section{Pembahasan}

Penelitian pengembangan ini menghasilkan media LKPD berbasis Daring pada materi oprasi hitung pecahan. Media LKPD berbasis Daring pada materi oprasi hitung pecahan yang dikembangkan berbeda dengan media LKPD lainnya karena belum ada yang mengembangkan media yang sejenis pada materi pada materi oprasi hitung pecahan di kelas V Sekolah dasar. Disamping itu, media yang dikembangkan dilengkapi dengan materi, gambar, video pembelajaran, dan soal-soal sesusai dengan materi yang diajarakan. Media LKPD berbasis daring dikembangkan berdasarkan hasil analisis kebutuhan di lapangan. Sehingga media ini dapat menjadi solusi dalam mengatasi permasalahan yang ada. Penggunaan media LKPD berbasis daring sangat cocok digunakan dalam proses pembelajaran jarak jauh atau pembelajaran secara daring. Hal ini dikatakan sesuai karena dalam penggunaan media siswa dapat membaca materi yang dilengkapi dengan gambar-gambar dan didukung dengan adanya video pembelajaran, sehingga siswa akan lebih paham akan materi yang dipelajari. Hal tersebut juga didukung oleh penelitian Pratiwi, (2016); Yuni et al., (2018) menyatakan pengunaan LKPD sangat membatu siswa dalam memahami suatu materi dan dapat memotivasi siswa dalam mengerjakan LKPD tersebut. Media LKPD berbasis daring pada materi oprasi hitung pecahan pada kelas $\mathrm{V}$ sekolah dasar dikembangkan dengan menggunakan model ADDIE. Model pengembangan ADDIE dugunakan karena terdapat tahapan pengembangan pembelajaran (Sari \& Lepiyanto, 2016). Tahap analysis dilaksanakan dengan menganalisis kebutuhan, menganalisis kurikulum, serta menganalisis media yang sesuai dengan kebutuhan. Berdasarkan tahap analisis yang dilaksanakan diperoleh bahwa media Media LKPD berbasis Daring pada materi oprasi hitung pecahan pada kelas V sekolah dasar sangat penting dan cocok untuk dikembangkan. Berdasakan kualifikasi yang didapat, media yang dikembangkan berada pada kualifikasi "sangat baik". Berdasarkan hal tersebut berarti bahwa media LKPD yang dikembangkan sangat layak dipakai sebagai media pembelajaran untuk siswa sekolah dasar. Secara teori, dalam pembelajaran untuk anak SD sangat diperlukan objek yang bersifat konkret terutama pada pembelajaran matematika (Ibda, 2015; Nusuf, 2018; Sutrimo \& Saharudin, 2019). Media memiliki validitas isi yang tinggi serta respons yang tinggi. Hal tersebut dikarenakan tujuan dari pembelajaran dalam media LKPD sudah sesuai dengan KD, materi dalam LKPD disampaikan secara jelas dan runtut serta sesuai dengan tingkat perkembangan karakteristik siswa, dan penjelasan materi pada LKPD dapat mendorong rasa ingin tahu siswa, dan validitas isi media LKPD mendapat kriteria validitas tinggi oleh ahli materi. Serta isi maupun video dari materi dalam LKPD ditampilkan secara jelas. Oleh karena itu, media LKPD ini dikembangkan untuk memfasilitasi hal tersebut karena media ini memiliki beberapa kelebihan dari media lainnya. Adapun kelebihan dari media LKPD daring ini adalah adalah tampilannya yang sangat menarik, dilengkapi dengan gambar dan video, mudah digunakan dan nilai yang diperoleh akan langsung muncul setelah selesai mengerjakannya sehingga pendidik tidak perlu repot-repot lagi untuk memeriksanya. LKPD daring ini memiliki nilai lebih dibandingkan LKPD cetak dan akan membantu peserta didik dalam memvisualisasikan materi yang bersifat abstrak (Awaluddin \& R., 2016; Khusnul et al., 2017). Implikasi dalam penelitian ini yaitu adanya media LKPD berbasis daring pada materi pecahan di kelas $\mathrm{V}$ sekolah dasar dengan kualifikasi sangat baik. Media ini dapat dimanfaatkan dalam proses pembelajaran daring pada mata pelajaran matematika khususnya materi oprasi hitung bilangan pecahan. Agar proses belajar mengajar secara daring maka guru perlu menyediakan media yang menarik dan mudah digunakan sehingga siswa akan lebih memahami materi yang diajarkan. Dengan adanya media LKPD berbasis daring ini dapat memfasilitasi siswa dalam pembelajaran jarak jauh dan tujuan dari pembelajaran bisa dicapai dengan baik.

\section{SIMPULAN}

Media LKPD pelajaran matematika materi operasi pecahan berbasis daring di kelas V sekolah dasar yang dikembangkan dinyatakan valid dan memiliki kualifikasi reliabilitas kuat serta memiliki kualifikasi sangat baik pada hasil uji coba terhadap siswa. Hal ini menunjukan bahwa media LKPD yang dikembangkan sangat layak digunakan dalam proses pembelajaran.

\section{DAFTAR PUSTAKA}

Asmuni. (2020). Problematika Pembelajaran Daring di Masa Pandemi Covid-19 dan Solusi Pemecahannya. Jurnal Penelitian Dan Pengembangan Pendidikan, 281-288. http://ojs.ikipmataram.ac.id/index.php/pedagogy/index.

Asriningtyas, A. N., Kristin, F., \& Anugraheni, I. (2018). Penerapan Model Pembelajaran Problem Based Learning Untuk Meningkatkan Kemampuan Berpikir Kritis Dan Hasil Belajar Matematika Siswa Kelas 4 SD. JKPM, 5(1), 23-32. jurnal.unimus.ac.id/index.php/JPMat.

Awaluddin, R. F. D., \& R., P. W. (2016). Pengembangan Modul Elektronik PCL Pada Standar Kompetensi Pemprogran Peralatan Sistem Pengendali Elektronik Dengan PCL Untuk SMK Raden Patah Kota Mojolerto. Jurnal Pendidikan Teknik EEektro, 5(3), 712-716. https://jurnalmahasiswa.unesa.ac.id/index.php/jurnal-pendidikan-teknik- 
elektro/article/view/16080/14602.

Effendi, R., Herpratiwi, \& Sutiarso, S. (2021). Pengembangan LKPD Matematika Berbasis Problem Based Learning di Sekolah Dasar. Jurnal Basicedu, 5(2), 920-929. https://jbasic.org/index.php/basicedu.

Egok, A. S. (2016). Kemampuan Berpikir Kritis Dan Kemandirian Belajar Dengan Hasil Belajar Matematika. Jurnal Pendidikan Dasar, 7(2), 186-199. https://core.ac.uk/download/pdf/297684592.pdf.

Faiqoh, A. N., Irianto, S., \& Anggoro, S. (2019). Pengembangan Lkpd Matematika Berbasis Higher Order Thinking Skills (Hots) Materi Bangun Ruang Kelas V Sekolah Dasar. Jurnal Elementaria Edukasia, 2(2), 103-106. http://dx.doi.org/10.31949/jee.v2i2.1484.

Fauzia, H. A. (2018). Penerapan Model Pembelajaran Problem Based Learning Untuk Meningkatkan Hasil Belajar Matematika SD. Primary: Jurnal Pendidikan Guru Sekolah Dasar, 7(1), 40-47. https://primary.ejournal.unri.ac.id/index.php/JPFKIP/article/download/5338/5006.

Hanifah, N. M., B., M. A. K., \& Budiman, M. A. (2019). Pengaruh Model Open Ended Problem Berbantu Media Kotak Telur Pelangi (Kotela) Terhadap Hasil Belajar Matematika. Journal of Education Technology, 3(3), 134139. http://dx.doi.org/10.23887/jet.v3i3.21734.

Hung, M. . (2016). No TitleTeacher readiness for online learning: Scale development and teacher perceptions. Computers \& Education, 94, 120-133. https://doi.org/10.1016/ j.compedu.2015.11.012.

Ibda, F. (2015). Perkembangan Kognitif: Teori Jean Piaget. Jurnal Intelektualita, 3(1). https://www.jurnal.arraniry.ac.id/index.php/intel/article/view/197.

Ilhami, R. S., \& R, D. (2017). Penilaian Kinerja Karyawan dengan Metode AHP dan Rating Scale. Jurnal Optimasi Sistem Industri, 16(2). https://doi.org/10.25077/josi.v16.n2.p150-157.2017.

Jr., L. D. L., Tiangcoa, C. E., Sumalinog, D. A. G., Sabarillo, N. S., \& Mark, J. (2021). An effective blended online teaching and learning strategy during the Covid-19 pandemic. Education for Chemical Engineers, 35, 116-131. https://doi.org/10.1016/j.ece.2021.01.012.

Kebritchi, M., Lipschuetz, A., \& Santiague, L. (2017). Issues and challenges for teaching successful online courses in higher education: A literature review. Journal of Educational Technology Systems, 46(1), 4-29. https://doi.org/10.1177/ 0047239516661713.

Khusnul, K., Ambarita, A., \& Fuad, M. (2017). Pengembangan Lembar Kerja Peserta Didik Tematik Berbasis Learning Cycle 5E. http://jurnal.fkip.unila.ac.id/index.php/pedagogi/article/viewFile/13455/pdf.

Komarudin, \& Permana, prisma T. (2019). LKPD Berbasis Scientific Approach Terhadap Kemampuan Pemecahan Masalah Peserta Didik Sekolah Dasar. Jurnal Pendidikan Dan Pembelajaran Dasar, 6(1), $79-91$. https://doi.org/10.24042/terampil.v6i1.4385.

Mishra, L., Gupta, T., \& Shree, A. (2020). Online teaching-learning in higher education during lockdown period of COVID-19 pandemic. International Journal of Educational Research Open, 1. https://doi.org/10.1016/j.ijedro.2020.100012.

Nawir, K. A., \& Pristiwaluyo, T. (2015). Penerapan Metode Demonstrasi Untuk Meningkatkan Keterampilan Melukis Peserta Didik Kelas XII IPA 3 SMA Negeri 1 Donri Donri Kabupaten Soppeng. Jurnal Penelitian Dan Evaluasi Pendidikan, 1(1). http://eprints.unm.ac.id/id/eprint/7757.

Nusuf, H. (2018). Pengembangan Lembar Kerja Peserta Didik (LKPD) Interaktif Berbasis Software Ispring pada Materi Larutan Penyangga. Banda Aceh: Universitas Syiah Kuala Banda Aceh. https://etd.unsyiah.ac.id/index.php?p=show_detail\&id=47727.

Oktaviani, W., Kristin, F., \& Anugraheni, I. (2018). Penerapan Model Pembelajaran Discovery Learning Untuk Meningkatkan Kemampuan Berpikir Kritis Dan Hasil Belajar Matematika Siswa Kelas 5 SD. Jurnal Basicedu, 2(2), 5-10. https://jbasic.org/index.php/basicedu/index.

Pahlevi, A., Damayani, A. T., \& Kiswoyo. (2019). Keefektifan Model NHT (Numbered Heads Together) Berbantu Media Sapuan Terhadap Hasil Belajar Matematika. International Journal of Elementary Education, 3(1), 9-15. /http://dx.doi.org/10.23887/ijee.v3i1.17278.

Permata, S. Y. (2019). Pengembangan LKPD Elektronik dengan 3D Pageflip Professional Berbasis Literasi Sains pada Materi Gelombang Bunyi. http://repository.radenintan.ac.id/8054/1/SKRIPSI.pdf.

Prasasti, D. E., Koeswanti, H. D., \& Giarti, S. (2019). Peningkatan Keterampilan Berpikir Kritis Dan Hasil Belajar Matematika Melalui Model Discovery Learning Di Kelas IV SD. Jurnal Basicedu, 3(1), 174-179. https://jbasic.org/index.php/basicedu.

Pratiwi, D. (2016). Pengembangan LKS Materi Pecahan Berbasis Pendekatan Kontekstual untuk Meningkatkan Hasil Belajar Siswa pada Kelas V SD di Kec. Tanjung Pura. http://digilib.unimed.ac.id/19671/.

Rahayu, D., \& Budiyono. (2018). Pengembangan Lembar Kerja Peserta Didik (LKPD) Berbasis Pemecahan Masalah Materi Bangun Datar. Jurnal Penelitian Pendidikan Guru Sekolah Dasar, 06(3), 249-259. https://jurnalmahasiswa.unesa.ac.id/index.php/jurnal-penelitian-pgsd/article/view/23506.

Rovers, S. F. E., Clarebout, G., Savelberg, H. H. C. M., \& van Merriënboer, J. J. G. (2018). Improving student expectations of learning in a problem-based environment. Computers in Human Behavior, 87, 416-423. https://doi.org/10.1016/j.chb.2018.02.016.

Sari, A. P. P., \& Lepiyanto, A. (2016). Pengembangan lembar kegiatan peserta didik (lkpd) berbasis scientific 
approach siswa sma kelas $x$ pada materi fungi. Bioedukasi, 7(1), 41-48. https://www.ojs.fkip.ummetro.ac.id/index.php/biologi/article/view/489/438.

Scherer, R., Howard, S. K., Tondeur, J., \& Siddiq, F. (2021). Profiling teachers' readiness for online teaching and learning in higher education: Who's ready? Computers in Human Behavior, 118, 1-16. https://doi.org/10.1016/j.chb.2020.106675.

Septian, R., Irianto, S., \& Andriani, A. (2019). Pengembangan Lembar Kerja Peserta Didik (LKPD) Matematika Berbasis Model Realistic Mathematics Education. Jurnal Educatio, 5(1), 59-67. https://doi.org/10.31949/educatio.v5i1.56.

Susilowati, E. (2018). Peningkatan Aktivitas dan Hasil Belajar Matematika Siswa SD Melalui Model Realistic Mathematic Education (RME) Pada Siswa Kelas IV Semester I Di SD Negeri 4 Kradenan Kecamatan Kradenan Kabupaten Grobogan Tahun Pelajaran 2017/2018. Jurnal PINUS, 4(1), 44-53. http://ojs.unpkediri.ac.id/index.php/pinus.

Sutrimo, K., \& Saharudin. (2019). LKPD bermuatan inquiry dan budaya Jambi: Efektivitas dalam meningkatkan kemampuan berpikir kreatif matematis. Indonesian Mathematics Education, 2(1), $29-36$. http://dx.doi.org/10.30738/indomath.v2i1.3841.

Tanjung, H. S., \& Nababan, S. A. (2016). Pengaruh Penggunaan Metode Pembelajaran Bermain Terhadap Hasil Belajar Matematika Siswa Materi Pokok Pecahan Di Kelas III SD Negeri 200407 Hutapadang. Jurnal Bina Gogik, 3(1), 35-42. https://www.ejournal.stkipbbm.ac.id/index.php/pgsd/article/view/26.

Tirka, W., \& Kusumawatin, N. M. (2017). Optimalisasi Model Pembelajaran Berbasis Masalah Dengan Berbantuan Lembar Kerja Siswa (LKS) Untuk Meningkatkan Aktivitas Dan Hasil Belajar. International Journal of Elementary Education, 1(1), 86-95. http://dx.doi.org/10.23887/ijee.v1i1.11443.

Wibawa, I. M. C., \& Arnawa, I. K. T. (2017). Penerapan Metode Inkuiri Berbantuan Media Benda Konkret Dapat Meningkatkan Hasil Belajar Matematika. International Journal of Elementary Education, 1(2), 129-136. http://dx.doi.org/10.23887/ijee.v1i2.11605.

Yuni, E., Ernawati, M. D. W., \& Malik, A. (2018). Pengembangan Lembar Kerja Peserta Didik Elektronik Berbasis Proyek pada Materi Termokimia di Kelas XI SMA. Journal of The Indonesian Society of Integrated Chemistry, 10(1), 6-11. https://doi.org/10.22437/jisic.v10i1.5306. 